\title{
The Existence of Balinese Hindu Women in the Aspect of Political Communication Study at Bali Women's Hindu Politician in Bali Provincial People's Legislative Council
}

\author{
Ni Gusti Ayu Ketut Kurniasari ${ }^{1}$, Eni Maryani², Dadang Sugiana ${ }^{3}$, Evie Ariadne Shinta \\ Dewi $^{4}$ \\ \{jegegyuke@gmail.com ${ }^{1}$,emaryani@gmail.com ${ }^{2}$, dadang.sugiana@unpad.ac.id ${ }^{3}$, \\ evie@unpad.ac.id $\left.{ }^{4}\right\}$
}

Faculty of Communication Science, Universitas Budi Luhur, Jl. Ciledug Raya, Jakarta, Indonesia ${ }^{1}$, Universitas Padjadjaran, Bandung, West Java, Indonesia ${ }^{2,3,4}$

\begin{abstract}
Balinese culture that embraces patriarchal system is able to provide its own color in the political activities undertaken by members of the Hindu female council in the Provincial House of Representatives of Bali Province. This study uses Edmund Hussell's phenomenology theory which aims to delve deeper into the conscious experience of Balinese women politicians in the Bali Provincial Legislative Council related to their existence in political communication. As a result of this research is the experience of Balinese women politicians in the Bali Provincial House of Representatives has been able to implementation of Balinese cultural traditions and Hindu teachings in the reality of life. The strength of Patrilineal culture is deservedly to encourage every Balinese family to be able to provide understanding and education about women's rights and obligations in Vedic teachings. The political dynasty as the reality of female Balinese women politicians in the Bali Provincial Legislative Council has been able to encourage all Hindu women's institutions to be more active in empowering the quality of Hindu women related to Hindu-based political education. The construction of meaning owned by Balinese women politicians in Balinese People's Legislative Council in the reality of political communication, is expected to have been able to improve the quality of Balinese women politicians in seeing every opportunity of their own existence.
\end{abstract}

Keywords: Existence, Politician Women, Patrilineal, Political Communication.

\section{Introduction}

The majesty of Balinese culture that is dominated by Hindus has its own characteristics, where every region in Indonesia has its own customs and culture. Thus, every citizen has an obligation to conserve and implement all customs and culture in earnest. Likewise with the customs and culture that exist in the Island of the Gods of Bali which until now was still firmly held firmly by the people of Bali.

The customs and culture that exist in Balinese society is closely related to the religion and religious life of the Hindu community. Both have long historical roots and reflect the expressive configuration with the dominance of religious values and philosophy of Hinduism. 
In the configuration is contained aspects of religious essence, lifestyle, community institutions, and art that exist in the Balinese community.

Bali province as adherents of the largest Hindus in Indonesia as in the data obtained by researchers, that the largest number of Hindus in Indonesia is on the island of Bali with details of the number of 3,419,436 people and the majority of the people also come from ethnic Balinese. If viewed in a cultural background that comes from ethnic Balinese and the majority embraced Hindu then this will be a very interesting thing to be studied. Bali as the dominance of the Hindus will have a different reality with Hindus outside the island of Bali which generally have acculturation with the local culture, such as Hindu Balinese ethnic in Lampung, Sulawesi and other regions in Indonesia [1].

The province of Bali as a region that still holds strong customs, has a patrilineal culture so strongly dominate, so the role of Balinese women becomes cornered and only limited to the domestic realm only. This can serve as one of the factors affecting the minimal involvement of women on the local and national political stage. Because talking about Hindu women's relevance in political participation cannot be separated from the interaction access and social involvement of women in every public sector. Because not only the quantity of numbers to be seen related to the involvement of women in the public sector, but also on the quality of women in interpreting every activity in the realm of political communication.

Related to the role of women in the realm of political communication, it is very important to understand how the role of women in Hinduism. As explained in the book of Manawa Dharmasastra that: According to as woman is expressed as land, man is manifested as seed; the result of the occurrence of the living bodily occurred because through the relationship between the ground and the seed in this book it is very clear that how men and women have the same duty in building a new life. Thus, it is fitting for Hindu women to take on more and more roles in their public activities [2].

The same position between men and women is also peeled in the book of Manawa Dharmasastra explaining that; In certain cases, the seeds are more prominent and other garbha women are prominent, but if both are the same, the derivatives will be greatly glorified. Where the book explains that, how men $=$ men and women have the same opportunities and opportunities to build a quality generation. So fitting men and women have the same space to build their own existence [2].

Related with existing data, stated that Hindu women more than men, and most in Bali Island as the majority of Hindus with the number of Hindu women as many as 1.805 .654 people while the number of second Hindu women in Lampung province with the number of 518,299 people and followed by other areas. Through these numbers certainly have hope there will be more Hindu women in the Province of Bali who dare to appear in the public arena as well as local and national political scene and able to give meaning in every political step. How does the construction of meaning in any political communication process done in both verbal and nonverbal communication in any social interaction, campaign, organization, publication, etc., will be able to give birth to a construction of its own political meaning for Hindu women in Bali Province [1].

\subsection{Problem Statement}

Based on background explanation, as for formulation of problem in this research are:

1. What is the experience of Balinese women politicians in the realm of Political Communication in the House of Representatives of Bali Province? 
2. How is the existence of female politicians of Balinese Hindu in the political communication domain in House of Representatives of Bali Province?

\subsection{Political Communication}

This research emphasizes on political communication as the foundation of reality owned by Balinese Hindu women in Indonesia especially in Bali Province Regional House of Representatives. How the construction of reality undertaken by these Hindu women becomes the focus of the process of verbal and non-verbal formation of meaning both as well as the philosophical expositions contained in the meanings held by the Hindu women.

Culture and Religion is still a major concern as the philosophical reason of Balinese Hindu women in Indonesia to engage more in their political communication activity, so it will be very interesting if the research process is able to express subjectively how the process of meaning formation related to the Hindu women's understanding in the activity political communication.

The dominance of patrilineal culture occurring in Balinese culture as Hindu dominant dominance is able to provide an interesting color to examine the understanding of Balinese Hindu women in Indonesia related to the political communication activity it performs. Patriarchal dominance in the world of politics is also able to be a separate consideration related to the opportunities and competition system owned by Balinese Hindu women in Indonesia.

Basically political communication has an important role in the system of government of a country that can be seen from the activities of political actors that exist both from the side of masculinity and feminists involved in the process of socialization and political interaction. Adapted to Rush and Althoff statements; 1997 [3]. Which states that "political communication plays a very important role in a political system. It is a dynamic element, and a decisive part of the processes of political socialization, political participation, and political recruitment. " While in the context of political socialization Graber; 1984 [3] states that "view this political communication as a process of learning, acceptance and approval of customs or rules, structures, and environmental factors that affect political life. It occupies an important position in social - political life because it can affect the quality of interaction between society and entrepreneurs".

Existing political communication, if the democratic system requires the existence of quality relations of power between the people and the ruler, then political communication becomes the determining factor of the form of democracy. Because the political system itself can not operate well without the support of the masses whose attitudes and political behavior are driven by the power of messages that are socialized through political communication activities.

If viewed from the cultural background of Balinese Hindu women in Indonesia and Bali Province in particular, it is necessary to look at the basic concepts between communication and culture and religion because political communication is also essentially a part of, and influenced by, the political culture of a society. At the same time, political communication can also give birth, preserve and pass on political culture. So with regard to the structure of messages and patterns of political communication played, it can be analyzed political culture of a society. 


\subsection{Hindu Women}

Discussing of Hindu women themselves, even in Hinduism, they have discussed the position of women themselves in social activities. This can be seen in the following quotation: 'strī hi brahmā babhsvitha'- a woman is actually a scholar, intelligent and able to teach in RgVeda VIII.33.19 [4]. In the quote RgVeda it is very clear that how Hindu women are asked to have a qualified capacity so as to take a role in society. Not only that, there are deep things that are also presented in the Vedas to Bhagavad Gita (Hindu religious scriptures) stating that; 'Samhotaram sma purā nārī, samanam vāva gacchati'-formerly the women went to the Agnihotra ceremony and advanced to the battlefield in Atharvaveda XX.126.1 [4]. This second quote clearly states that men and women have the same role even in battlefields.

Hinduism is basically gives great freedom to every Hindu woman to take a role in her social activities. But in reality, Hindu teachings cannot be realized well when clashing with the traditions and culture that exist in the province of Bali. The uniqueness and uniqueness of Balinese culture is inseparable from the patriarchal culture that comes from the Balinese patrilineal kinship system. Patriarchal culture in Balinese culture is based on the existence of the concept of Purusha and Predana, which symbolizes the soul (spirit) is immortal (Purusha), and human physics that have a changing nature (Prakirti). In society, the concept is better known for things related to men or Purusha, and things related to women or Predana. This concept serves as a basis for differentiating status and roles between women and men, which in certain cases cannot replace each other. This Hindu philosophy then animates the Balinese cultural ideology, which evolves into a system of values, norms and rules, called patrilineal patriarchal and customary laws, which function as social controls [5].

\subsection{Existence}

The existence can be interpreted by various experts. As in the great dictionary of Indonesian Existence is the existence, the presence of which contains elements of perseverance. In this case, the existence in question is certainly associated with the presence and presence of the Hindu women in the province of Bali in the realm of political communication. Not only as a passive actor, but the intended existence can be interpreted as an active activity undertaken in the realm of political communication.

In a journal written by Irfan Ardani in the journal Lakon: Journal of literary and cultural studies vol. 1 no. 2 | July 2013, describes some definitions of the word existence, as described by Hadiwijono, which states that existence is derived from the ex (exit) and sistensi derived from the verb sisto (standing, putting). The word existence means that man stands by himself by coming out of himself. Man is aware that he exists. While different definitions are expressed by Loren Bagus, which states that existence comes from the existence word derived from the Latin existere which means to appear, exist, arise, or have actual existence. Existere itself comes from the word $e x$ which means out and sistere which means appear [6].

\subsection{Phenomenology of Edmund Husserl}

This research will use the theory of Phenomenology as a knife of analysis to dissect and answer research problems. Where the main essence of the theory of phenomenology is to explore the subjective consciousness of humans in this case is a Hindu female politician in Bali Province. Where in this study, all informants will be the meaning of political experience and interpret every political activity that he did. 
Phenomenological tradition according to (Creswell, 1998) which states that "Whereas a biography reports the life of a single individual, a phenomenological study describes the meaning of the lived experiences for several individuals about a concept or the phenomenon" [7]. The study of phenomenology thus attempts to explain the meaning of the life experiences of some people about a concept or phenomenon, which in this case is a Hindu female politician in the province of Bali including the self-concept or view of their own life.

The same thing is also expressed by Mulyana [8] that "the approach of phenomenology includes a subjective or interpretive approach, which views human beings as active, in contrast to the objective approach or behavioristic and structural approaches assuming that humans are passive". While phenomenology according to Maurice Natanson [8] "the term phenomenology can be used as a generic term to refer to all social science views that place human consciousness and its subjective meaning as the focus for understanding social action."

Husserl emphasizes that there is no conceptual scheme beyond the actual experience which is sufficient to reveal the truth; so the conscious experience of the individual must be the route to finding reality, only through the conscious attention of the truth can be known. In other words, we can know everything in the world by investigating it in a clear way.

Husserl also tried to describe the value of one's experience in the method of phenomenology namely "Most phenomenologists today would say that experience is subjective, not objective, and that we need to value subjectivity as an important kind of knowledge in its own sake". The most important thing in phenomenology is when saying experiences are subjective rather than objective and we need the value of subjectivity which is an important thing to gain knowledge toward an interest [9].

The experience of a passive past, related to the time of the beginning of events, the temporary circumstances that occur and other experiences of this type is not very influential (in terms of giving meaning). Understanding the benefits of experience should be more than "ego action (Attitude Attitude) or some change of an action (secondary passivity, or perhaps the sudden passivity of decision making" to me ") [9].

As Husserl's statement [10] states that "We define" behavior "as an experience of consciousness that bestes meaning through spontaneous activity." As well as "In the direction of the occurrence or running-off of the behavior, the spontaneous Act is nothing more than the mode of intentionality in which the constituting objectivity is given. In other words, behavior as it occurs is "perceived" in a unique way as primordial activity. "

Husserl tries to apply a concept of the problems that exist to ourselves, in which we define "behavior" as an experience of consciousness that provides understanding through spontaneous activity. And spontaneous action is no more than a deliberate way of defining the given objectivity; in other words, such behavior is occurring "perceived" in a unique way as a primordial activist [10].

\section{Research Methods}

Paradigm is like a window where people observe the outside world, where people start to explore the world with the insight (world-view). But in general, the paradigm can be interpreted as a set of beliefs or basic beliefs that lead a person in acting in everyday life. This understanding is in line with the Guba conceptualized by Thomas Kuhn as a fundamental set of beliefs that guide our actions, both in daily actions and in scientific investigations [11]. 
In this study using an ontological Constructivist Paradigm, it states that reality exists in the form of various mental constructions, based on social experience, local and specific and dependent on the person doing so. Therefore, a reality observed by a person cannot be generalized to everyone as is usually done in positivist and post positivist positions. Because of this philosophical basis, according to this flow is a unity, subjective and is the result of a combination of interaction between the two [11].

These subjective meanings are often socially and historically negotiated. These meanings are not simply printed to be distributed to individuals, but must be made through interaction with them (hence the so-called social constructivism) and through the historical and social norms prevailing in their daily lives. These meanings should also be emphasized in the particular context in which these individuals live and work so that researchers can understand their historical and cultural background.

Therefore, the implementation of this method of phenomenological research, will actually explore the conscious experience of Balinese women politicians in the Bali Provincial Legislative Council. Where the conscious experience will be generated through in-depth interview conducted by the researcher, so that all informants will be able to interpret all the reality they have very freely in accordance with their respective subjectivity.

\subsection{Data Collection Technique}

Researchers will use several techniques for the process of collecting data in this study. The technique is adapted to the method used, the needs of researchers in obtaining data and phenomena in this study. Researchers see participant observation, interview and literature study able to represent data collection technique in this research.

Observation Participation, ie direct observation on the location of the study to get a clear picture - clearly about the object of research. By doing direct observation, researchers are expected to find out how Hindu female politicians in Bali Province construct the reality they have.

In order to express the reality of female politicians of Hinduism in Bali Province in the context of qualitative communication, the researcher posed various open questions to the research subjects. Interviews that researchers do is an in-depth interview, is informal and unstructured. Mengutif Lindloft, interview that researchers do aims to "develop a view of something between (inter) people" [12]. The interviews that researchers do are "conversation with a purpose" [12]. Therefore the question structure that the researcher designs is not a standard guideline, but as signposts or gratings. Sometimes researchers ask other questions or ask them to elaborate on their answers.

\section{Research Result}

Based on interviews that have been done by researchers to some informants namely female politicians Hindu Bali as a Member of the House of Representatives of the Province of Bali. Interviews were held with I Gusti Ayu Diah Werdhi (Member of House of Representatives of Bali Province from PDI Perjuangan Fraction), Mrs. Kadek Darmini (Member of House of Representatives of Bali Province from PDI Perjuangan Fraction), Mrs. Made Arini (Member of House of Representatives of Bali Province from Hanura Fraction) 
Utami Dwi Suryadi (Member House of Representatives of Bali Province from Demokrat Faction).

In addition to research interviews, researchers also made observations in place of the informants perform activities such as, the Bali Provincial Parliament building and the workspace of the informants. Interviews were conducted at agreed locations with informants prior to the interview. Where interviews can be done in the hotel lobby, office lobby, representative offices of political parties, as well as informant workspace.

\subsection{The Experience of Hindu Women Politicians in the aspect of Political Communication in Bali Province.}

\subsubsection{Implementation of Hindu Culture and Religion in Bali Province}

Balinese culture is based on the patriarchal system by placing a very strategic male position in patrilineal family life, men have their own power and power in the family and society level. The lineage and attachment to the ancestor, very strong only seen from the male lineage. In Balinese families, women are only a complement to family activity as well as in society, because the kinship system is only determined by male lineage.

The role of men and women in Balinese culture has a huge difference. In a Balinese family order, women have multidimensional and multi gender roles as mothers, wives, workers, family members and social members, as well as organizers of religious rituals. Even the practice of Hinduism in Balinese custom is driven by the majority of Balinese Hindu women. It is precisely this that gives rise to the perception of Balinese women who are described as being persistent, tenacious, strong and independent but have high adherence value (devotion) to the husband's family.

The research informants presented in the language of Bali, which states, "haroohhh dadi nak loh Bali to nak tuyoh bu, mekejang gaenin. (Ough, so the Balinese woman was very tired, everything have to do) ". Even some research informants claim to have despair if already in a state of exhaustion with daily activities that have been done.

Interestingly, women politicians should be able to negotiate with their families and local Banjar to better understand their very crowded activities and sometimes cannot attend directly in some activities in the Banjar. Although initially the people are still reluctant to give them the sincerity to not attend, but efforts are still made to maximize their activities in the public aspect. As stated by Kadek Darmini stating that: "Waahh, tyang (I) must involve many families to be involved in the Banjar. Not only my husband tyang (me), even my father-in-law (I) must be involved. Like yesterday there is karye (ceremony) in Banjar tyang (me), pas tyang (me) cannot attend, and husband tyang (me) also again there is activity, then my in-law tyang (who) finally must come".

In line with that delivered by I Gusti Ayu Diah Werdhi stating that: "I should be able to build a good coordination with my husband and children. All my family members make the team. Otherwise, it will be our time to share. "

Various ways must be done by Hindu female politicians, where patrilineal culture sometimes requires them to be tough in all aspects of life. When his devotion is complete in the house, then after that the Balinese women's politicians are just able to step out of the house for the move.

The high value of adherence (devotion) provided by Balinese women to the husband's family, resulted in high levels of domestic violence. The Legal Aid Institute (LBH) noted, during 2015, 120 cases of domestic violence up to the persecution. Of these cases, 30 cases of 
women and 27 children who experienced violence (KDRT) and Legal Aid Institute (LBH) Bali also said, every day Polresta (Police) Denpasar received complaints of three victims of domestic violence experienced by women [13].

It was also conveyed by informants who wholly agreed that the devotion of Hindu women was extraordinary both to her family and to her husband's family. As Mrs. Made Arini puts it in a vigorous intonation, stating that: "The devotion of Balinese Hindu women is remarkable, until sometimes we do not think of ourselves. All the affairs from inside the house to the outside of the house like upakara (ceremonial) should we women who take care of it. Where did the man know the kitchen problem until manyah meli banten (pay purchase Banten / Sajen / Canang)"

The exhaustion of Hindu Women in the province of Bali in the domestic realm can be seen clearly, where their ability to negotiate with their husbands and families is an important thing to do. So there is a reluctance to be more active in the public aspect. The Hindu women politicians assume that the Balinese women's mind and energy seems to be depleted in domestic matters as well as religious ceremonies and upakara (ceremonial) that must be done, so that the space of socialization and space to build the quality of self in society tends to be a forgotten thing.

\subsubsection{Political Dynasty as the Reality of Hindu Women Politicians in Bali Province}

The interesting fact that happens in the realm of political communication in the province of Bali is the political reality that is almost the same as other areas, namely the dominance patriarchies system. Where politics is the world of men. What is interesting, however, is that the political reality in the province of Bali is now more interesting with the emergence of two female regional heads despite the patrilineal culture. So the emergence of two regional heads are able to become a motivation for the Hindu women in Bali Province.

But the condition, many are still asking how the process of Hindu female politicians to be able to exist and appear to color the stage of political communication stage in Bali Province. Many doubted the abilities of these Hindu female politicians, and were always associated with political power held by their parents and by their husbands. It is usually referred to as dynastic politics. Where the politics of self-rule can be interpreted as a political power run by a group of people who are still related in family relationships. Basically, the political dynasty is more authentic with the kingdom, because the power will be passed down from generation to generation to father or even now develop from husband to wife, so that power will remain in the family circle.

It is openly acknowledged by the women politicians, where they sometimes state that they do not really like politics. However, due to the demands of their husbands and their adherence to their husbands or fathers who make them must be willing to plunge into the political world and take part to appear in the realm of political communication.

As stated by Mrs. Kadek Darmini who said that: "I politicized it because my husband who had jumped first here. My husband is already two periods in the Regency DPRD, so when there is a chance he immediately asked me to come, though in fact I myself was not sure then ". Although the process is assisted by the husband, but Mrs. Darmini Kadek also continue to plunge into the community that is sometimes accompanied by her husband.

The development of political dynasties that now exist in the province of Bali, will tend to have an impact on the process of quality formation of the Hindu female politicians. so it can be interpreted that, the formation of female politicians of Hinduism in Bali Province still on quantity not on quality only. The activities of female Balinese Hindu politicians are still 
limited to the fulfillment of women quota, not on the main essence to work and produce works for Hindu community in Bali Province.

\subsection{The Existence of Hindu Women Politicians in the Aspect of Political Communication in Bali Province.}

\subsubsection{Opportunities of Self-Existence of Hindu Women Politicians in Bali Province}

The different roles between men and women are also very clearly visible in the social fabric of Balinese society, where the structure of society in Balinese culture only provides opportunities for men to engage in public activities. This is why the Balinese family should have a son, because to be a purusa (male / leader / eternal) as the heir and a continuation of lineage or lineage in the culture of Bali. Boys should be able to replace the parent's position as a community member (banjar) when their parents are old or the boy is married. This is because, every activity of Balinese society such as meeting in banjar (society) usually only presents the head of family of male sex. But in fact in the social relations of the community, banjar acknowledged that married citizens consist of lanang (male, or head of household) and wife (female). Meanwhile, unmarried members are included in tereka teruna (clusters of youth). This shows that, the political role of men and women in Balinese culture ranging from banjar is very different.

The group of men takes a role in political decision making which is then implemented by the banjar members. While the role of women take more portion as the executor of the course. Even if the women's group meetings, itupun addressed as an extension of the command program to carry out the agenda decided by the authorities or government, such as Posyandu, gymnastics and Arisan PKK (regular Social Gathering), etc. So it can be seen that, political decisions in the smallest society that exist in the Province of Bali was already dominated by men.

The same thing was also conveyed by one informant who with a sad expression explains that: "That's the condition of our society today, sometimes we are still difficult to get a chance to speak in public. But this we can not be flat around the whole of Bali, because there are some Banjar that have been given the opportunity for women to talk, but still there are Banjar that only prioritize men only, "said Mrs. Made Arini in soft tones. From his expression, as there is a deep concern to be expressed in the reality.

In contrast to that delivered by Mrs. Dwi Utami Suryadi stating that; "Women's opportunity to talk is actually wide open, just how women should be able to grasp the opportunity. But most importantly, the woman dare not speak? And indeed the need for education about the rights of Hindu women who started from the family first just go to society ". So it can be said that, the family also has an important role to educate Hindu women to dare to appear in the public space, so that more and more Hindu women who appear in the political communication aspect.

\subsubsection{The Existence of Hindu Women Politicians in Bali Province}

Hindu women are still reluctant to appear in the public aspect, it can be seen still at least the number of female politicians who advanced in the arena of political communication in the province of Bali. Most informants say that, not all husbands allow their wives to perform, even if allowed, the wife must be able to meet some requirements that must be met. 
This can be seen from the lack of involvement of Balinese Hindu women in the political arena and also as one political communicator other than academic and professional, is still very minimal, as the following data that based on the law should reach 30 percent, but from a total of 55 members of the board only five of them women and still very small numbers. The names of the five members of the House of Representatives of Bali Province are Ni Putu Yuli Artini SE (Faction of Golongan Karya Party), Ni Made Sumiati, SH (PDI Perjuangan Faction), Ni Kadek Darmini SE (PDI Perjuangan faction), Dra. Utami Dwi Suryadi (Democratic Party Faction), and Made Arini (Conscience Party Faction).

In relation to the existence of Hindu women politicians in the realm of political communication in the province of Bali, of course, becomes a very interesting thing to understand, where in its own activities, Hindu women politicians are still focused to build their own existence. So the Hindu female politicians tend to build a comfort zone in their activities. In a political activity undertaken by Hindu female politicians, there is a tendency of these Hindu women politicians to tend to build discussions with only female politicians, but when asked which one is more invited to work together, the answer is male politicians. This could be the reason that, the existence of Hindu women politicians in the province of Bali should still continue to be explored in the openness of the quality of self-owned by the Hindu female politicians.

\section{Discussion}

\subsection{The Experience of Hindu Women Politicians in the Aspect of Political Communication in Bali Province}

Related with the experience of Hindu politicians in Bali Province is strongly influenced by the implementation of patrilineal culture prevailing in Bali Province as well as the implementation of Hinduism's own teachings. Most of the female politicians of Hinduism in Bali Province tend to be burdened with exhaustion with cultural implementation which is sometimes unfavorable for women when viewed from self-actualization which will be done.

Thus, it is necessary to have a great understanding for the education of women in Hinduism especially in relation to the rights and obligations of women that are actually regulated in the Vedic scriptures that begin with the immediate environment of the family. So Hindu women, especially Hindu women politicians will be better able to understand and interpret every role that will be acted both in everyday life and in the realm of political communication.

Thus, if the understanding of Hinduism, it is hoped not only will be able to produce generation of Hindu women who really excel in quality. This will be able to build the confidence of Hindu women to always appear in their own qualities, not because of the political dynasty that happened during this time. Very important also made the empowerment of women related to Hindu-based political education. So that hope will emerge the politicians of Hindu women who are very prepared in quality to color the stages of political communication in the province of Bali. 


\subsection{Existence of Hindu Women Politicians in the realm of Political Communication in Bali Province.}

Based on the experience generated by these Hindu female politicians, it will produce constructs of constructed meanings subjectively. Where the resulting meaning has a close relationship to the perspective that will be owned by the Balinese women's Hindu politicians. How the perspective is built, will certainly determine how the quality of Balinese Hindu women are in view of every political opportunity it has. Where every political opportunity is expected to be able to strengthen the political existence of Hindu women politicians in the realm of Political Communication in Bali Province.

So it can be said that, the quality of understanding and the political significance of Hindu female politicians is largely determined by the reality of the experience possessed by each of the Hindu female politicians. Likewise, Hindu female politicians to establish their existence in the realm of political communication. So hopefully, more and more Hindu female politicians will dare to appear to show their existence in the realm of political communication.

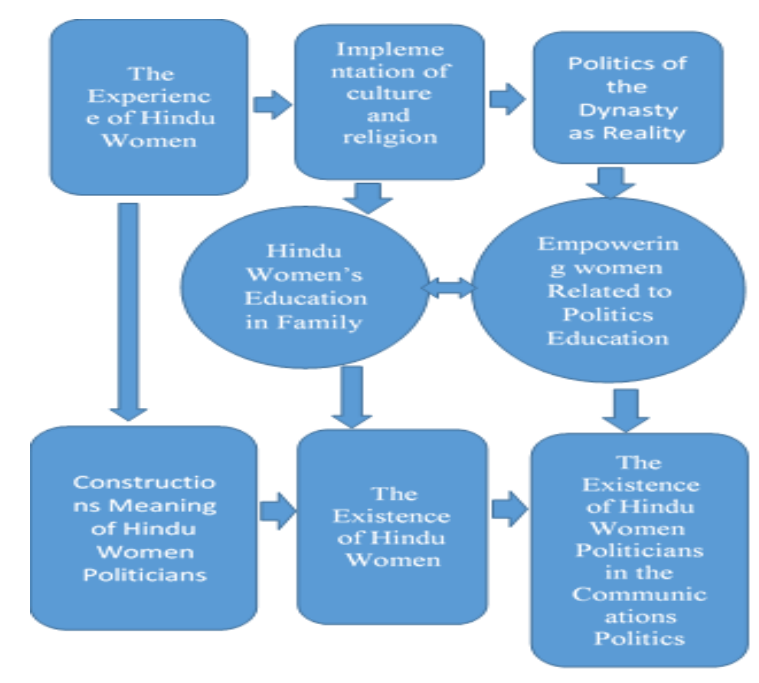

Fig. 1. The existence model of Hindu women politicians in Bali province.

\section{Conclusion}

As for conclusion in this research are:

1. The experience of Balinese women politicians in the Bali Provincial Legislative Council has been able to implement Balinese cultural traditions and Hindu teachings in the reality of their lives. The strength of patrilineal culture is deservedly to encourage every Balinese family to be able to provide understanding and education about women's rights and obligations in Vedic teachings.

2. The political dynasty as the reality of the female politicians of Balinese Hindu women in the Bali Provincial Legislative Council has been able to encourage all Hindu women's institutions to be more active in empowering the quality of Hindu women related to 
political education based on Hinduism. As well as the construction of meaning owned by Balinese women politicians in Balinese Provincial House of Representatives in reality of political communication, is expected to have been able to improve the quality of Balinese women politicians in seeing every opportunity of their own existence.

\section{References}

[1]Ditjen Bimas Hindu, “Data Umat Hindu Indonesia,” Kemenag RI, 2013. .

[2]G. Pudja and T. R. Sudharta, Manawa Dharmacastra. Jakarta: Pelita Nursatama Lestari, 2002.

[3]A. S. Muhtadi, Komunikasi Politik Indonesia, Dinamika Islam Politik Pasca-Orde Baru. Bandung: Remaja Rosdakarya, 2008.

[4]Bhagavad Gita Scripture. Hanuman Sakti.

[5]N. Made, D. Widayani, and S. Hartati, "Kesetaraan Dan Keadilan Gender Dalam Pandangan Perempuan Bali : Studi Fenomenologis,” J. Psikol. Undip, vol. 13, no. 2, pp. 149-162, 2014.

[6]P. Jawab et al., LAKON; Jurnal Kajian Sastra dan Budaya, no. Sastra \& Budaya. .

[7]J. W. Creswell, Qualitative Inquiry And Research Design; Choosing Among Five Traditions. SAGE Publication, 1998.

[8]D. Mulyana, Metodologi Penelitian Kualitatif, Paradigma Baru Ilmu Komunikasi Dan Ilmu sosial Lainnya. Bandung: PT Remaja Rosdakarya, 2004.

[9]S. In, Phenomenology § Philosophy. .

[10]G. Walsh and F. Lehnert, The Phenomenology of The Social World. London: Heinemann Educational Books, 1972.

[11]A. Salim, Teori Dan Paradigma Penelitian Sosial. Yogyakarta: Tiara Wacana Yogya, 2001.

[12]T. R. Lindlof, Qualitative Communication Research Methods, Current Communication: An Advanced Text Series Volume 3. SAGE Publications, 1995.

[13]Rhm, Setiap Hari Tiga Perempuan di Denpasar Alami KDRT. 